\title{
Efektifitas Validasi Bea Perolehan Hak atas Tanah dan Bangunan terhadap Ketidaksesuaian Nilai Objek Pajak dalam Akta Jual Beli dengan Harga Sebenarnya
}

\section{Effectiveness of Validation of Duties on Acquisition of Rights on Land and Buildings against Incompatibility of Value of Tax Objects in the Deed of Sale and Purchase with the Actual Price}

\author{
Dejan Gemelar Raja Guk-Guk, Isnaini*, M. Citra Ramadhan \\ Magister Hukum, Fakultas Hukum, Universitas Medan Area, Indonesia
}

Diterima: 03 Juni 2021 Direview: 03 Juni 2021; Disetujui: 28 September 2021

*Coresponding Email: isnaini@staff.uma.ac.id

\begin{abstract}
Abstrak
Penelitian ini bertujuan untuk mengetahui efektivitas validasi Bea Perolehan Hak atas Tanah dan Bangunan (BPHTB) terhadap ketidaksesuaian nilai objek pajak, proses validasi BPHTB dan cara menentukan Nilai Pokok Objek Pajak (NPOP) yang sesuai dengan nilai objek pajak yang sebenarnya, yang dilakukan oleh Dinas Pendapatan Daerah Kota Medan (BPPRD). Jenis penelitian adalah penelitian normative yang bersifat deskriptif. Efektivitas validasi BPHTB terhadap ketidaksesuaian nilai objek pajak dilihat berdasarkan data penerimaan BPHTB tersebut diatas diketahui bahwa jumlah target dan realisasi pajak BPHTB terlihat tahun 2017 sampai 2019 adalah cukup efektif. Proses validasi BPHTB yang dilakukan oleh BPPRD Kota Medan secara umum sudah cukup memuaskan, ditambah lagi saat ini proses validasi SSPD BPHTB dilakukan dengan sistem online, sehingga proses validasi SSPD BPHTB menjadi lebih mudah dan cepat. Cara Menentukan Nilai Pokok Objek Pajak (NPOP) dengan menentukan nilai transaksi pada transaksi jual beli. Penggunaan nilai transaksi yang digunakan sebagai dasar perhitungan BPHTB ini seringkali menimbukan permasalahan. Perbedaan nilai transaksi yang yang disepakati oleh para pihak dan dituangkan dalam akta dengan nilai transaksi yang digunakan sebagai dasar perhitungan BPHTB menurut penelitian BPPRD, dalam hal ini terjadi ketidakpastian nilai mana yang benar, sehingga menentukan NPOP yang sesuai dengan nilai objek pajak yang sebenarnya menjadi sulit, kecuali dengan dilakukan verifikasi lapangan atas objek BPHTB tersebut.
\end{abstract}

Kata Kunci: Efektifitas; Validasi; Bea Perolehan Hak atas Tanah dan Bangunan.

\section{Abstract}

This study aims to determine the effectiveness of the validation of Land and Building Rights Acquisition Duty (BPHTB) against tax object value discrepancies, the BPHTB validation process carried out by the Medan City Regional Revenue Service (BPPRD) and how to determine the Tax Object Principal Value (NPOP) in accordance with the actual value of the tax object. This type of research is a descriptive normative research. The effectiveness of BPHTB validation against the discrepancy in the value of tax objects is seen based on the BPHTB revenue data mentioned above, it is known that the number of targets and realization of BPHTB taxes seen from 2017 to 2019 is quite effective. The BPHTB validation process carried out by the Medan City $B P P R D$ in general is quite satisfactory, plus currently the BPHTB SSPD validation process is carried out with an online system, so that the BPHTB SSPD validation process becomes easier and faster. How to determine the Principal Value of the Tax Object (NPOP) by determining the transaction value in the sale and purchase transaction. The use of the transaction value used as the basis for calculating BPHTB often creates problems. The difference in the transaction value agreed by the parties and stated in the deed with the transaction value used as the basis for calculating BPHTB according to BPPRD research, in this case there is uncertainty about which value is correct, so determining the NPOP in accordance with the actual value of the tax object becomes difficult. except by conducting field verification on the said BPHTB object.

Keywords: Effectiveness; Validation; Fees for Acquisition of Land and Building Rights.

How to Cite: Raja Guk-Guk, D.G. Isnaini, \& Ramadhan, M.C. (2021), Efektifitas Validasi Bea Perolehan Hak atas Tanah dan Bangunan terhadap Ketidaksesuaian Nilai Objek Pajak dalam Akta Jual Beli dengan Harga Sebenarnya, Journal of Education, Humaniora and Social Sciences (JEHSS), 4(2), 875-885 


\section{PENDAHULUAN}

Bea Perolehan Hak Atas Tanah dan Bangunan (BPHTB) merupakan pajak yang dikenakan atas perolehan hak atas tanah dan atau bangunan (Ayza, 2018). Perolehan Hak Atas Tanah dan Bangunan adalah perbuatan atau peristiwa hukum yang mengakibatkan diperolehnya hak atas tanah dan atau bangunan oleh orang pribadi atau badan. (Kadir, 2018). Dalam melakukan pemungutan BPHTB menggunakan Self Assessment System, dimana wajib pajak dipercayakan untuk menghitung, membayar sendiri dan melaporkan pajak yang terhutang sesuai dengan peraturan perundang-undangan perpajakan sehingga penentuan besarnya pajak yang terhutang dipercayakan kepada Wajib Pajak (Mardiasmo, 2011).

Validasi terhadap BPHTB dilakukan untuk mengetahui dan memastikan mengenai kebenaran data peralihan hak atas tanah dan bangunan yang tercantum dan tertera dalam Surat Setoran Pajak Daerah Bea Perolehan Hak Atas Tanah dan Bangunan (SSPD BPHTB) yang dihitung sendiri oleh wajib pajak karena sistem pemungutan BPHTB adalah secara Self Assesment System. (Ambat dkk, 2020; Wirawan, 2019).

Pemungutan BPHTB adalah salah satu bagian yang sangat penting dalam proses peralihan hak (balik nama) atas tanah dan bangunan di Indonesia, karena Notaris dan Pejabat Pembuat Akta Tanah (PPAT) dilarang untuk menandatangani akta peralihan hak sebelum wajib pajak melunasi BPHTB sebagaimana mestinya (Siahaan, 2010). Dalam praktek, seringkali ditemukan harga transaksi jual beli atas tanah dan bangunan yang terjadi dalam peralihan hak maupun pemberian hak baru tidak sesuai dengan harga transaksi yang sebenarnya, bahkan jauh dibawah harga pasar yang sebenarnya, yang digunakan sebagai dasar NPOP dalam penghitungan BPHTB, (Siahaan, 2019).

Dalam transaksi jual beli, PPh harus dibayar sesuai ketentuan dan BPHTB harus dibayar sesuai harga pengalihan hak atas tanah dan bangunan yang sebenarnya. Dalam hal inilah pentingnya validasi BPHTB dilakukan, selain untuk mengetahui tentang kebenaran dan keberadaan objek pajak serta kelengkapan data perolehan hak atas tanah dan bangunan, juga untuk menghindari penghindaran-penghindaran pajak yang dapat dilakukan oleh wajib pajak, karena sistem pemungutan pajak BPHTB dilakukan dengan Self Assesment System, wajib pajaklah yang menentukan dan menghitung sendiri pajak BPHTB yang akan dibayarnya. (Saleh \& Kamello, 2014; Nainggolan, 2016).

Teori yang digunakan adalah teori Efektifitas dan teori Kepastian hukum, teori Efektifitas, bahwa suatu sikap tindak perilaku hukum dianggap efektif, apabila sikap, tindakan atau perilaku lain menuju pada tujuan yang dikehendaki, artinya apabila pihak lain tersebut mematuhi hukum. (Soekanto, 1982). Efektifitas adalah pengukuran dalam arti tercapainya sasaran atau tujuan yang telah ditentukan sebelumnya. Soerjono Soekanto menggunakan tolak ukur efektivitas dalam penegakan hukum pada 5 (lima) hal yakni: (Soekanto, 2007) 1. Faktor Hukum; 2. Faktor Penegakan Hukum; 3. Faktor Sarana atau Fasilitas Pendukung; 4. Faktor Masyarakat; 5. Faktor Kebudayaan

Teori efektifitas digunakan dalam penelitian untuk menjawab tentang sejauh mana kegiatan validasi oleh petugas Dinas Pendapatan Daerah Kota Medan berdasarkan Peraturan Walikota Medan Nomor 9 Tahun 2011 Tentang Pelaksanaan Peraturan Daerah Kota Medan Nomor 1 Tahun 2011 Tentang Bea Perolehan Hak Atas Tanah Dan Bangunan sebagai peraturan pelaksanaan yang dikeluarkan oleh Pemerintah Daerah Nomor 1 Tahun 2011 Tentang Bea Perolehan Hak Atas Tanah Dan Bangunan memberikan dampak positif bagi wajib pajak untuk mengikuti ketentuanketentuan yang terkait terhadap ketidaksesuaian nilai objek pajak yang menjadi dasar pemungutan pajak BPHTB terhadap nilai transaksi sebenarnya.

Teori kepastian hukum mengandung 2 (dua) pengertian yaitu: "Pertama, adanya aturan yang bersifat umum membuat individu mengetahui perbuatan apa yang boleh atau tidak boleh dilakukan, dan kedua berupa keamanan hukum bagi individu dari kesewenangan pemerintah karena dengan adanya aturan hukum yang bersifat umum itu individu dapat mengetahui apa saja yang boleh dibebankan atau dilakukan oleh negara terdapat Individu. Kepastian hukum bukan hanya berupa pasal-pasal dalam Undang-Undang melainkan juga adanya konsistensi dalam 
putusan hakim antara putusan hakim yang satu dengan putusan hakim lainya untuk kasus yang serupa yang telah di putuskan". (Marzuki, 2008)

Dalam azas yuridis, segala sesuatu yang berkenaan dengan pemungutan pajak harus ditetapkan dalam peraturan perundang-undangan untuk menghindari kesewenang-wenangan serta terjadinya penyelewengan di dalam pemungutan pajak. Pajak yang harus dibayar oleh wajib pajak harus jelas dan pasti. "Kepastian itu meliputi Subjek dan Objek pajak, tarif dan dasar pengenaan pajak dan lain-lain.

Berdasarkan hasil penelusuran sementara dan pemeriksaan yang dilakukan ditemukan beberapa peneltian mengenai Bea Perolehan Hak Atas Tanah Dan Bangunan (BPHTB), yaitu : "Tinjauan Yuridis Terhadap Pemungutan Bea Perolehan Hak Atas Tanah dan Bangunan (BPHTB) Dalam Transaksi Jual Beli Tanah Dan Bangunan Di Kota Tanjung Balai, oleh Chairumi (2014), dalam artikel ini disebutkan bahwa Kantor Badan Pertanahan. Hasil penelitian menunjukkan bahwa meskipun badan hukum Bank SUMUT berubah menjadi Badan Usaha, tetap mempertahankan surat utangnya dan tidak mengalami proses pendaftaran perubahan nama dalam surat utangnya. Menurut PT Bank SUMUT, alasan memiliki surat utang didasarkan pada Surat Keputusan Menteri Dalam Negeri No. SK.61/DJA/1979 tentang Pengangkatan Bank Pembangunan Daerah sebagai badan hukum dan karena seluruh sahamnya dimiliki oleh pemerintah dan seluruh kekayaannya tidak berubah, sedangkan kewajiban Bank SUMUT atas kekayaannya diatur dalam anggaran dasar yang diatur dalam Anggaran Dasar Pemegang Saham.. Tesisi berjudul "Pemungutan Bea Perolehan Hak Atas Tanah Dan Bangunan (BPHTB) Dalam Jual Beli Tanah Atau Bangunan Di Kota Semarang" (Ariyanti, 2006). Penelitian ini disimpulkan, bahwa BPHTB dalam pelaksanaannya menggunakan sistem selfassessment dan prosedur pembayarannya sangat sederhana karena tidak menggunakan Surat Ketetapan Pajak. PPAT/Notaris memiliki peranan yang signifikan dalam pemungutan BPHTB karena PPAT/Notaris adalah pejabat umum yang terkait dengan transaksi jual beli tanah, PPAT/Notaris akan menandatangani akta otentik setelah pajak BPHTB tersebut dibayar lunas oleh Wajib Pajak.

Dilihat dari titik permasalahan yang telah dilakukan pada penelitian sebelumnya terdapat adanya perbedaan khususnya pada permasalahan yang akan dibahas dalam penelitian ini. Penelitain ini bertujuan untuk menganalisis efektivitas validasi BPHTB terhadap ketidaksesuaian nilai objek pajak, untuk menganalisis proses validasi BPHTB yang dilakukan oleh Dinas Pendapatan Daerah Kota Medan dan untuk menganalisis cara menentukan Nilai Pokok Objek Pajak (NPOP) agar sesuai dengan nilai objek pajak yang sebenarnya.

\section{METODE PENELITIAN}

Jenis penelitian yang dilakukan dalam penelitian ini adalah penelitian hukum normative. penelitian yang dilakukan bersifat deskriptif yaitu penelitian yang hanya menggambarkan faktafakta tentang objek penelitian baik dalam kerangka sistematisasi maupun sinkronisasi berdasarkan aspek yuridis, dengan tujuan menjawab permasalahan yang menjadi objek penelitian (Sunggono, 2001). Dalam penelitian ini menggunakan metode pengumpulan data kepustakaan atau library research. Penulis menggunakan sumber bahan hukum Primer, Sekunder dan Tertier. Metode pendekatan dalam penelitian ini dilakukan melalui pendekatan perundang-undangan (statute approach). Metode yang digunakan dalam penelitian ini adalah dokumentasi. Metode ini digunakan untuk memperoleh data yang sifatnya dokumen, seperti buku register dan arsip-arsip atau dokumen khusus lainnya. Data yang terkumpul akan diidentifikasikan kemudian dilakukan penganalisisan secara kualitatif.

\section{HASIL DAN PEMBAHASAN}

\section{Efektivitas Validasi Bphtb Terhadap Ketidaksesuaian Nilai Objek Pajak}

Bea Perolehan Hak Atas Tanah dan Bangunan (BPHTB) adalah pajak yang dikenakan atas perolehan hak atas tanah dan atau bangunan. Pemungutan BPHTB diatur dalam Undangundang Nomor 28 tahun 2009 tentang Pajak Daerah dan Retribusi Daerah. Terdapat 3 (tiga) unsur 
yang terkandung dari bea perolehan hak atas tanah dan bangunan (BPHTB), yaitu bea (pajak), perolehan, hak atas tanah dan bangunan.

Berdasarkan Pasal 4 ayat (1) UU BPHTB yang menjadi subjek pajak adalah orang pribadi atau badan yang memperoleh hak atas tanah dan atau bangunan (Siahaan, 2010). Objek dari Bea Perolehan Hak atas Tanah dan Bangunan (BPHTB) adalah perolehan hak atas tanah dan bangunan, sedangkan Perolehan hak atas tanah dan atau bangunan adalah perbuatan atau peristiwa hukum yang mengakibatkan diperolehnya hak atas dan atau bangunan oleh orang pribadi atau badan. Undang-Undang BPHTB mengatur bahwa perolehan hak atas tanah dan bangunan yang menjadi obyek pajak terdiri karena 2 (dua) hal, yaitu: Pemindahan Hak dan Pemberian Hak Baru (Siahaan, 2003). Tarif Pajak Bea Perolehan Hak atas Tanah dan Bangunan (BPHTB) paling tinggi ditetapkan paling tinggi sebesar 5\% (lima persen) dan ditetapkan dengan Peraturan Daerah Kabupaten/Kota yang bersangkutan (Waluyo, 2010).

Dasar Pengenaan Bea Perolehan Hak Atas Tanah dan Bangunan (BPHTB) adalah Nilai Perolehan Objek Pajak (NPOP). Nilai Perolehan Objek Pajak adalah harga transaksi atau nilai pasar atas tanah dan bangunan yang dialihkan atau diperoleh yang dimuat dalam akta peralihan hak, risalah lelang atau pemberian hak baru.

Sesuai dengan Undang-Undang Nomor 28 Tahun 2009 Pasal 87 ayat (4) dan (5), besaran Nilai Perolehan Objek Pajak Tidak Kena Pajak (NPOPTKP) ditetapkan paling rendah sebesar Rp.60.000.000,00 (enampuluh juta rupiah) untuk setiap Wajib Pajak. Dalam hal perolehan hak karena waris atau hibah wasiat yang diterima orang pribadi yang masih dalam hubungan keluarga sedarah dalam garis keturunan lurus satu derajat ke atas atau satu derajat ke bawah dengan pemberi hibah wasiat, termasuk suami/istri, Nilai Perolehan Objek Pajak Tidak Kena Pajak ditetapkan paling rendah sebesar Rp.300.000.000,00 (tiga ratus juta rupiah).

Perhitungan Bea Perolehan Hak atas Tanah dan Bangunan menurut Undang-Undang Nomor 28 Tahun 2009 Pasal 89 adalah :

BPHTB $=$ max 5\% X (NPOP-NPOPTKP) atau Max 5\% X (NJOP-NPOPTKP)

Apabila NPOP tidak diketahui atau lebih kecil daripada NJOP, maka perhitungan BPHTB adalah sebagai berikut:

Pajak terutang $=$ Tarif pajak $x$ Dasar pengenaan pajak = Tarif pajak x (NJOP-NPOPTKP)

\section{Efektivitas Validasi BPHTB Terhadap Ketidaksesuaian Nilai Objek Pajak}

Kriteria penilaian efektivitas berdasarkan pada Kepmendagri Nomor 690.900.327 tahun 1996 tentang Pedoman Penilaian dan Kinerja Keuangan dinyatakan sebagai berikut: 1). Tingkat pencapaian di atas 100\% berarti sangat efektif; 2). Tingkat pencapaian antara 90\% - 100\% berarti efektif; 3). Tingkat pencapaian antara $80 \%$ - 90\% berarti cukup efektif; 4). Tingkat pencapaian antara $60 \%$ - 80\% berarti kurang efektif; 5). Tingkat pencapaian di bawah $60 \%$ berarti tidak efektif

Indikator efektivitas pemungutan pajak tidak hanya dapat dilihat dari kinerja kantor pajak daerah dalam merealisasikan target penerimaan pajak, namun juga dilihat dari kinerja dalam menjaring wajib pajak baru melalui kegiatan ekstensifiksi dan intensifikasi pajak serta kepatuhan wajib pajak itu sendiri, (Hasil wawancara dengan A. Untung Lubis) termasuk pemungutan pajak BPHTB melalui system self assessment.

Berdasarkan data yang diperoleh dari BPPRD Kota Medan, jumlah penerimaan pajak BPHTB dalam kurun waktu 3 (tiga) tahun terakhir, yaitu tahun 2017, 2018 dan 2019 terdapat data sebagai berikut:

Table 1. jumlah penerimaan pajak BPHTB dalam kurun waktu 3 (tiga) tahun terakhir, yaitu tahun 2017, 2018 dan 2019

\begin{tabular}{llllll}
\hline No. & Tahun Anggaran & Target & Realisasi & $\%$ & Jumlah WP \\
\hline 1. & 2017 & 336.974 .000 .000 & 402.547 .433 .426 & $119.46 \%$ & 13.880 \\
\hline 2. & 2018 & 339.974 .000 .000 & 275.741 .255 .103 & $81.11 \%$ & 14.846 \\
\hline 3. & 2019 & 370.085 .122 .322 & 302.724 .851 .911 & $81.80 \%$ & 13.965 \\
\hline
\end{tabular}

Sumber: A. Untung Lubis, Kabid BPHTB dan PBB BPPRD Kota Medan

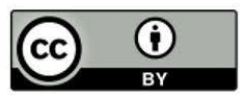


Berdasarkan data penerimaan BPHTB tersebut diatas diketahui bahwa jumlah target dan realisasi pajak BPHTB terlihat untuk tahun anggaran 2017, penerimaan pajak BPHTB melebihi dari target yang telah ditetapkan, yaitu sebesar $119.46 \%$, hal ini berati tingkat efektivitasnya cukup efektif. Sedangkan untuk 2 (dua) tahun terakhir yaitu tahun 2018 dan tahun 2019 penerimaan pajak BPHTB mengalami penurunan dari target yang telah ditetapkan dan masih mengalami selisih yang cukup besar, yaitu tahun anggaran 2018 sebesar $81.11 \%$ dan penurunan juga terjadi di tahun 2019, yaitu sebesar $81.80 \%$ dari target yang telah ditetapkan. Dengan begitu besarnya tingkat efektivitas pajak BPHTB yang diterima pada tahun 2018 dan tahun 2019 berada pada kriteria Kurang efektif.

Tingkat efektivitas dapat dihitung dengan membandingkan antara realisasi penerimaan pajak BPHTB Kota Medan dengan target anggaran yang telah ditentukan oleh BPPRD Kota Medan pada periode tertentu. Tingkat efektivitas yang dicapai dapat mencapai presentase mendekati. Berdasarkan tabel di atas dapat diketahui jumlah target penerimaan dan realisasi penerimaan pajak BPHTB Kota Medan dapat digunakan untuk mengetahui tingkat efektivitas penerimaan pajak BPHTB. Berdasarkan data juga diketahui bahwa jumlah target pajak BPHTB serta jumlah realisasi perolehan pajak BPHTB ternyata belum maksimal sehingga belum seperti yang diharapkan.

\section{Prosedur Pemungutan Bea Perolehan Hak Atas Tanah dan Bangunan (BPHTB)}

Pemungutan BPHTB menganut 5 (lima) prinsip pemungutan, yaitu: (Hernanda, 2014): a) Pemenuhan kewajiban BPHTB adalah berdasarkan sistem Self Assessment, yaitu WP menghitung dan membayar sendiri utang pajaknya; b) Besarnya tarif ditetapkan sebesar 5\% (lima persen) dari Nilai Perolehan Obyek Pajak Kena Pajak (selanjutnya disingkat NPOPKP); c) Agar Pelaksanaan UU BPHTB dapat berlaku secara efektif, maka baik kepada WP maupun kepada pejabat-pejabat umum yang melanggar ketentuan atau tidak melaksanakan kewajibannya, dikenakan sanksi menurut peraturan Perundang-undangan yang berlaku; d) Hasil penerimaan BPHTB merupakan penerimaan Negara yang sebagian besar diserahkan kepada Pemerintah Daerah, untuk meningkatkan pendapatan daerah guna membiayai pembangunan daerah dalam rangka memanfaatkan otonomi daerah.

Prosedur pemungutan BPHTB terdiri dari (Pratiwi, 2018): 1) Pembayaran BPHTB, Wajib pajak melakukan pembayaran BPHTB terutang dengan menggunakan SSPD BPHTB. Pembayaran dilakukan oleh Wajib Pajak melalui bendahara penerimaan dan/atau pembantu bendahara penerimaan pada DPPRD untuk disetorkan ke kas daerah hari kerja berikutnya; 2) Penelitian SSPD BPHTB, Pembayaran BPHTB diteliti oleh petugas penilai dan pemeriksa pajak pada DPPRD. Penelitian SSPD BPHTB dilakukan oleh petugas penilai dan pemeriksa pajak daerah pada seksi pendataan, pendaftaran, penetapan dan penagihan atas kebenaran dan kelengkapan SSPD BPHTB dan dokumen pendukungnya. Langkah-langkah yang teknis yang dilakukan dalam penelitian BPHTB terhadap pelaksanaan pembayaran BPHTB ini adalah: a) Wajib Pajak akan menerima SSPD BPHTB yang telah diisi. Surat Setoran BPHTB merupakan surat yang oleh Wajib Pajak digunakan untuk melakukan pembayaran atau penyetoran pajak yang terutang ke Kas Daerah atau tempat lain yang ditetapkan Walikota dan sekaligus untuk melaporkan data perolehan hak atas tanah dan/atau bangunan; b) Wajib pajak menyerahkan SSPD BPHTB kepada Bank yang ditunjuk/Bendahara Penerimaan. Pada saat yang bersamaan, Wajib Pajak kemudian membayarkan BPHTB terutang melalui Bank yang ditunjuk/Bendahara Penerimaan; c) Bank yang ditunjuk/Bendahara penerima kemudian memeriksa kelengkapan pengisian SSPD BPHTB kesesuaian besar nilai BPHTB terutang dengan uang pembayaran yang diterima dari Wajib Pajak; d) Bank yang ditunjuk/Bendahara penerimaan menandatangani SSPD BPHTB lembar 5 dan 6 disimpan sedangkan lembar 1-4 dikembalikan kepada Wajib Pajak; e) Wajib Pajak menerima SSPD BPHTB lembar 1,2,3, dan 4 dan bank yang ditunjuk/bendahara penerimaan, Wajib Pajak kemudian melakukan proses berikutnya, yaitu permohonan penelitian SSPD BPHTB ke fungsi pelayanan di Dinas Pendapatan Pengelolaan Keuangan dan Aset Daerah (DPPKAD) (Raja Gukguk: 2019). 
Pelaporan BPHTB. Pelaporan BPHTB bertujuan untuk memberikan informasi tentang realisasi penerimaan BPHTB sebagai bagian dari pendapatan asli daerah. Bendahara penerimaan dan atau pembantu bendahara penerimaan menyiapkan laporan BPHTB berdasarkan pembayaran langsung, bukti rekening koran dari bank yang ditunjuk. Penagihan BPHTB, Penagihan dilakukan untuk menagih BPHTB terutang yang belum dibayar oleh Wajib Pajak.Penagihan dilaksanakan melalui penetapan Surat Tagihan Pajak Daerah (STPD) dan/ atau Surat Ketetapan Pajak Daerah Kurang Bayar (SKPDKB) BPHTB dan/ atau Surat Ketetapan Pajak Daerah Kurang Bayar Tambahan (SKPDKBT) BPHTB. STPD dan/ atau SKPD jika setelah jatuh tempo tidak dibayar akan diterbitkan surat teguran dan/ atau surat paksa. Pengurangan BPHTB, Pengurangan BPHTB dilakukan oleh Wajib Pajak dan disampaikan kepada petugas pelayanan untuk diteliti. Pengembalian BPHTB, Wajib Pajak mengajukan pengembalian atas kelebihan pembayaran BPHTB. Pemungutan dilakukan dengan menggunakan self assessment system yaitu Wajib Pajak diberikan kepercayaan untuk menghitung dan membayar sendiri pajak yang terutang dengan menggunakan Surat Setoran Bea Perolehan Hak atas Tanah dan Bangunan (SSB) serta melaporkannya tanpa mendasarkan pada surat ketetapan pajak. Dalam pemungutannya, pembayaran dapat melalui Kepala Desa, petugas DPPRD an bahkan disetorkan melalui Bank yang ditetapkan oleh pemerintah daerah Kota Medan yaitu Bank Sumut.

\section{Proses Validasi BPHTB Yang Dilakukan Oleh Badan Pengelola Pajak Dan Retribusi Daerah (BPPRD) Kota Medan}

Validasi adalah penentuan harga dalam peralihan hak jual beli atas bidang tanah tertentu yang dilakukan oleh warga masyarakat atau pengecekan tanda bukti setoran pembayaran Bea Perolehan Hak atas Tanah dan Bangunan (BPHTB) (Mulyoto: 2016). Tata cara validasi dialihkan dan disesuaikan kepada masing-masing Pemerintah Daerah, dan Pemerintah Daerah mempunyai aturan sendiri-sendiri dalam melakukan validasi. BPPRD Kota Medan menjalankan tugas dan kewenangannya dalam pengelolaan keuangan dan aset daerah sebagaimana mestinya menurut aturan yang berlaku dalam Pemerintah Daerah.

Berdasarkan hasil penelitian, Standart Operational Prosdure (SOP) pendaftaran BPHTB adalah sebagai berikut: (Sumber data Badan Pengelola Pajak dan Retribusi Daerah (BPPRD) Kota Medan)

Langkah pertama, wajib pajak mengajukan permohonan BPHTB dengan menyertakan berkas validasi BPHTB. Kemudian, kelengkapan berkas yang harus disiapkan oleh wajib pajak adalah berkas yang sudah ditandatangani oleh wajib pajak dan PPAT, Fotocopy KTP wajib pajak, Fotocopy bukti kepemilikan tanah, Fotocopy SPPT PBB sesuai tahun berjalan, Fotocopy AJB/PJB (jika sudah dikeluarkan oleh PPAT) dan bukti lunas PBB (taanpa tunggakan PBB).

Langkah kedua, petugas loket pelayanan BPHTB mencetak nomor pendaftaran berkas validasi BPHTB dengan membawa berkas pendukung beserta lembar pendaftaran berkas validasi BPHTB. Kemudian petugas loket pelayanan BPHTB menyerahkan berkas validasi kepada petugas validator BPHTB untuk dibukukan dan dibuatkan tanda terima pendaftaran berkass validasi BPHTB.

Ketiga, petugas validator BPHTB menyerahkan/melaporkan berkas validasi BPHTB kepada Kasubbid Teknis BPHTB dan PBB untuk diparaf dan dilakukan pemeriksaan kelengkapan berkas validasi, kemudian setelah itu berkas validasi diparaf. Selanjutnya, dilakukan verifikasi kelengkapan dan pemisahan berkas, melalui cek tunggakan PBB dan cek kondisi objek bumi dan bangunan.

Tahap selanjutnya dilakukan verifikasi secara online data SSPD BPHTB (objek yang merupakan tanah kosong dilakukan verifikasi lapangan. Setelah dilakukan verifikasi lapangan, kemudian dilakukan approval oleh Kabid BPHTB dan PBB untuk berkas yang telah sesuai. Berkas yang telah di approval kemudian di print out lembar SSPD BPHTB. Setelah print out lembar SSPD BPHTB keluar, waib pajak/PPAT siap melakukan pembayaran di loket penerimaan BPHTB melalui bank persepsi (Bank Sumut). SSPD BPHTB yang telah dibayar kemudian dapat dilakukan validasi.

\section{http://mahesainstitute.web.id/ojs2/index.php/jehss \\ (1) mahesainstitut@gmail.com}


Pada dasarnya penelitian SSPD BPHTB dimaksudkan untuk memastikan kebenaran pembayaran pajak, tetapi dalam keadaan tertentu dapat dilakukan penelitian terhadap BPHB nihil. Hal ini di kenal sebagai penelitian SSPD BPHTB nihil, penelitian ini dimaksudkan untuk memastikan bahwa apakah benar atas perolehan hak tersebut tidak ada BPHTB yang terutang (nihil). Pada dasarnya tata cara penelitian SSPD BPHTB, baik yang telah dibayar oleh wajib pajak maupun SSPD BPHTB nihil tidak ada perbedaan.

Penelitian yang penulis lakukan pada Kantor BPPRD Medan, penelitian atas SSPD BPHTB yang tidak dikenakan penelitian lapangan akan selesai dalam waktu tiga-empat hari kerja. Setelah berkas SSPD BPHTB lulus tahapan verifikasi dan validasi atas nilai transaksi yang di canturnkan dalam SSPD BPHTB, maka SSPD BPHTB sudah bisa di cetak. Jika wajib pajak melakukan input SSPD BPHTB dari kantor Notaris/PPAT, maka SSPD harus di cetak dari Kantor Notaris/PPAT tersebut, SSPD BPHTB yang sudah lolos validasi akan terdapat tulisan "APPROVED" pada kolom kiri paling bawah SSPD BPHTB, SSPD BPHTB yang sudah approved di cetak sebanyak 6 (enam) lembar, dan setiap lembar harus di beri stempel dan di bubuhi tandatangan Notaris/PPAT.

Penelitian atas Surat Setoran Pajak Daerah BPHTB dapat di lanjutkan dengan penelitian lapangan jika diperlukan. Berdasarkan penelitian yang dilakukan di Kantor BPPRD Medan, penelitian lapangan atas SSPD BPHTB biasanya dilakukan pada SSPD BPHTB yang memiliki kriteria tertentu, sebagaimana dibawah ini: a) Apabila terdapat perbedaan data antara SSPD BPHTB dan SPPT PBB atau basis data PBB. Maksudnya ialah terdapat perbedaan nama pada SPPT PBB yang tercantum dalam SSPD PBB dengan nama yang tertera pada basis data PBB yang diinili ki oleh Dispenda; b) Terdapat bangunan yang belum masuk dalam basis data PBB (tanah kosong). Maksudnya ialah pada permohonan penelitian SSPD BPHTB bangunan di kosongkan mengikuti pada SPPT PBB yang ada, pada kenyataannya dilapangan, petugas lapangan pengelola pajak menemukan fakta bahwa atas tanah kosong tersebut telah berdiri bangunan rumah permanen. Dalam hal ini petugas lapangan mengelola pajak atas SSPD BPHTB akan mengembalikan berkas dan serta melampirkan foto bangunan yang telah berdiri diatas tanah tersebut sebagai bukti bahwa di atas tanah kosong tersebut telah berdiri bangunan rumah. Penyelesaian atas temuan lapangan ini biasanya petugas mengelola pajak akan meminta wajib pajak untuk merubah basis data PBB dengan menambahkan Luas bangunan sesuai dengan yang ada dilapangan pada SPPT PBB. dengan demikian maka, nilai perolehan atas SPPD BPHTB tersebut akan bertambahnya nilainya atau akan terjadi kenaikan dalam pembayaran pajak. C) Terdapat bangunan dalam basis data PBB tetapi tidak dicantuinkan dalam SSPD BPHTB. Maksudnya ialah, setiap berkas permohonan yang kita mohonkan untuk dilakukan ppenelitian akan melewati tahan pencocokan data yang ada pada SSPD BPHTB dengan basis data PBB. jika pada basis data PBB tercantum bangunan tapi tidak dicantumkan pada SSPD BPHTB hal ini bisa saja terjadi karena wajib pajak ingin menghindari pajak yang besar, sehingga tidak mencantumkan luas bangunan dalam SPPD BHPHTB, dalam hal ini petugas lapamngan penelitian SSPD BPHTB akan meminta wajib pajak untuk merevisi SPPT PBB dengan fakta yang ada dilapangan. d) Nilai transaksi yang dicantumkan pada SSPD BPHTB dibawah nilai NPOPTKP yaitu sesuai dengan NJOP yang ada pada SPPT PBB. Maksudnya ialah, penggunaan nilai transaksi juga mempengaruhi dalam proses penelitian lapangan atas SSPD BPHTB. Nilai transaksi yang digunakan dalam SSPD BPHTB seharusnya adalah dengan mencantum nilai perolehan yang sebenarnya, tapi pada kenyataannya wajib pajak banyak yang mencantumkan nilai transaksi dengan menggunakan NJOP pada SPPT PBB. dalam peralihan hak jual beli, NPOPTKP adalah senilai Rp. 60.000.000,- (enam puluh juta rupiah). Sebagai contoh: jika NJOP atas SPPT PBB yang menjadi objek peralihan hak adalah senilai Rp.59.000.000,- (lima puluh sembilan juta rupiah), biasanya wajib pajak juga akan membuat nilai transaksi pada SSPD BPHTB adalah senilai dengan NJOP yaitu Rp. 50.000.000,- (lima puluh sembilan juta rupiah), maka dari itu jumlah pajak yang di setorkan wajib pajak adalah NIHIL atau tidak ada atau dengan kata lain nol rupiah. Mengingat di Kota Medan jarang sekali nilai jual atas tanah dan bangunan yang masih dibawah NPOPTKP. Banyak temuan dilapangan atas penelitian SPPD BPHTB atas SPPT PBB yang NJOPnya dibawah NPOPTKP ternyata fakta dilapangan bahwa nilai perolehan atas tanah dan bangunan tersebut bisa naik tiga kali lipat dari NJOP yang ada di SPPT PBH dan juga bentuk 
bangunan yang sudah renovasi serta bertambahnya luas bangunan yang tidak di cantumkan pada SPPT PBB. Dari temuan ini, maka petugas pajak akan akan memberitahu temuan lapangan atas SSPD BPHTB kepada wajib pajak atau pihak terkait lain atau yang dikuasakan untuk merubah besarnya nilai transaksi yang ada pada SSPD BPHTB dan juga Akta peralihan hak Notaris/PPAT dengan harga yang sebenarnya dilapangan serta merevisi SPPT PBB dengan menambahkan luas bangunan yang bertambah.

Sesuai dengan Undang-undang Nomor 25 Tahun 2009 pasal 57 ayat 4 dan 5, besaran Nilai Perolehan Objek Pajak Tidak Kena Pajak ditetapkan paling rendah sebesar Rp. 60.000.000,00 (enam puluh juta rupiah) untuk setiap wajib pajak. Dalam hal perolehan hak karena waris atau hibah wasiat yang diterima orang pribadi yang masih dalam hubungan keluarga dalam garis keturunan lurus satu derajat ke atas atau satu derajat kebawah dengan Memberi hibah wasiat, termasuk suami/istri, NPOPTKP ditetapkan paling rendah sebesar Rp. 300.000.000,- ( tiga ratus juta rupiah), NPOPTKP tetapkan dengan peraturan daerah. Nilai Perolehan Objek Pajak Tidak Kena Pajak pada dasarnya merupakan suatu besaran tertentu dari nilai peroehan objek pajak (NPOP) yang tidak dikenakan pajak. Hal ini berarti apabila NPOP yang menjadi dasar pengenaan pajak kurang dari besaran NPOPTKP yang di tetapkan pada suatu kabupaten/kota, maka atas objek pajak tersebut tidak ada BPHTB yang harus dibayar oleh wajib pajak atau dengan kata lain tidak terutang BPHTB. Sementara apabila NPOP besarnya lebih dari NPOPTKP yang di tetapkan maka objek pajak tersebut akan dikenakan pajak, dimana besarnya pajak terutang dihitung dari selisih antara NPOP dan NPOPTKP.

Penggunaan nilai transaksi memang sangat mempengaruhi proses validasi SSPD BPHTB, sebab data yang disampaikan kepada BPPRD untuk di verifikasi harus valid dengan nilai yang sebenarnya. Jika ternyata data yang diberikan tidak valid maka BPPRD akan menerbitkan Surat Ketetapan Pajak Daerah Kurang Bayar Tambahan terhadap objek hak yang tersebut.

Jika pada saat pencocokan nilai transaksi dengan nilai pasar dalam penentuan pajak BPHTB menimbulkan perbedaan NPOP yang cenderung lebih tinggi dari NJOP PBB, maka apabila wajib pajak merasa keberatan atas NPOP yang ditentukan tim pemeriksa, wajib pajak dapat mengajukan banding dengan melampirkan bukti-bukti dan alasan pengajuan banding. Ketika wajib pajak mengajukan keberatan/banding atas harga transaksinya tim pemeriksa akan melakukan penelitian atas kebenaran nilai transaksi yang di ajukan oleh wajib pajak dengan melihat bank data base di kantor BPPRD Kota Medan, serta mencocokan Nilai Objek Pajak yang ada di BPHTB dengan yang ada di SPPT PBB, serta mencocokan luas yang ada di SPPT PBB dengan yang di sertipikat. (Hasil wawancara dengan A. Untung Lubis)

Secara umum proses validasi BPHTB yang dilakukan oleh Badan Pengelola Pajak Dan Retribusi Daerah (BPPRD) Kota Medan sudah cukup memuaskan, ditambah lagi saat ini proses validasi SSPD BPHTB dilakukan dengan sistem online, sehingga proses validasi SSPD BPHTB menjadi lebih mudah dan cepat.

\section{Cara Menentukan Nilai Pokok Objek Pajak (NPOP) Yang Sesuai Dengan Nilai Objek Pajak Yang Sebenarnya}

Sistem Pemungutan BPHTB. Berdasarkan pemeriksaan maka fiskus akan menetapkan apakah wajib pajak telah melunasi pajak terutang sesuai dengan ketentuan atau tidak. Dengan demikian maka dapat diketahui apakah pajak dibayar semestinya, terdapat kelebihan pembayaran pajak ataupun kekurangan pembayaran pajak terutang. Ada 4 (empat) surat ketetapan pajak yang mungkin dikeluarkan oleh fiskus kepada wajib pajak, yaitu: (Siahaan, 2010): Surat Ketetapan BPHTB Nihil (SKBN); Surat Ketetapan BPHTB Lebih Bayar (SKBLB); Surat Ketetapan BPHTB Kurang Bayar (SKBKB); Surat Ketetapan BPHTB Kurang Bayar Tambahan (SKBKBT).

Penagihan Pajak adalah serangkaian tindakan agar penanggung pajak melunasi utang pajak. Tindakan penagihan pajak dimaksud meliputi: menegur dan memperingatkan, melaksanakan oenagihan pajak seketika dan sekaligus (PPSP), memberitahukan surat paksa (SP), mengusulkan pencegahan, melaksanakan penyitaan dan menjual barang-barang yang telah disita

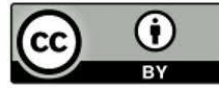


dan/atau melaksanakan penyanderaan (Ayza, 2018). Hak-hak Wajib Pajak Pada Bea Perolehan Hak Atas Tanah Dan Bangunan (BPHTB): 1). Keberatan; 2). Banding; 3). Pengurangan

Dalam Undang-Undang Nomor 28 tahun 2009 dalam Pasal 87 ayat (1) menyatakan bahwa dasar pengenaan Bea Perolehan Hak Atas Tanah dan Bangunan (BPHTB) adalah Nilai Perolehan Objek Pajak (NPOP). Pada ayat (3) menyatakan jika NPOP sebagaimana dimaksud pada ayat (2) huruf a sampai $n$ tidak diketahui atau lebih rendah dari pada NJOP maka yang digunakan dalam pengenaan pajak bumi bangunan (PBB) pada tahun terjadinya perolehan dasar pengenaan yang dipakai adalah NJOP PBB.

Berdasarkan ketentuan yang dimaksud dalam Pasal 87 ayat (3) Undang-Undang Nomor 28 tahun 2009 tersebut diatas mengatakan bahwa dasar pengenaan BPHTB pada peralihan hak akibat jual beli adalah berdasarkan NPOP berdasarkan harga transaksi, jika lebih rendah atau tidak diketahui maka digunakan NJOP PBB. Hal ini seringkali menjadi persoalan ketika pelimpahan kewenangan mengenai pajak daerah ditentukan sendiri oleh masing-masing daerahnya sehingga sulit untuk mengetahui secara pasti berapa nilai NPOP yang digunakan dalam setiap transaksi jual beli.

Penggunaan nilai transaksi yang digunakan sebagai dasar perhitungan BPHTB ini seringkali menimbukan permasalahan. ketentuan tentang dasar yang digunakan sebagai dasar perhitungan BPHTB baik yang diatur dalam Undang-Undang BPHTB maupun dalam Undang-Undang PDRD adalah dengan menggunakan nilai transaksi. Nilai transaksi adalah nilai yang merupakan kesepakatan antara para pihak yang melakukan transaksi, seperti dalam jual beli adalah antara penjual dengan pembeli. Sehingga kepastian hukum nilai transaksi turut dalam menentukan sah tidaknya sebuah jual beli, dalam hal ini apakah benar bahwa nilai transaksi baik yang dicantumkan dalam akta jual beli maupun yang digunakan sebagai perhitungan BPHTB adalah benar sesuai dengan kenyataan yang telah disetujui atau disepakati oleh pihak-pihak yang melakukan transaksi.

Kesepakatan harga yang telah disepakati oleh para pihak (penjual dan pembeli) mengikat secara sah sebagai Undang-Undang, penjual dan pembeli bebas menentukan isi dan syarat-syarat perjanjian termasuk dalam penentuan harga jual beli. Harga jual beli yang telah disepakati oleh para pihak tersebut mengikat bagi penjual dan pembeli.

Dalam UU No 25 Tahun 2009 tentang Pajak Daerah dan Retribusi Daerah Pasal 25 mengatur bahwa dasar pengenaan BPHTB adalah nilai perolehan objek pajak. Sedangkan harga transaksi berdasarkan Nilai Perolehan Objek Pajak (NPOP) untuk jual beli adalah harga transaksi, dengan dasar nilai transaksi ini, maka nilai dasar yang digunakan dalam perhitungan BPHTB tergantung dari kesepakatan para pihak dalam melakukan transaksi. Sehingga kepastian kebenaran nilai transaksi yang dianggap telah di setujui dan menjadi dasar perhitungan BPHTB tergantung dari kejujuran para pihak. Tidak menutup kemungkinan nilai transaksi yang digunakan tersebut tidak sesuai dengan yang sebenarnya atau memang para pihak yang melakukan transaksi jual beli tersebut sepakat mengadakan jual beli dengan harga yang cukup rendah atau dengan harga di bawah pasar karena sebab-sebab tertentu.

Hal ini tentunya tidak mudah untuk menjamin kepastian bahwa nilai transaksi yang digunakan sebagai dasar perhitungan BPHTB itu adalah nilai transaksi yang sebenarnya atau tidak. Hal demikian wajar dapat saja terjadi penurunan harga, mengingat pada umumnya para pihak menghendaki pembayaran pajak yang lebih ringan. Dalam hal ini maka diperlukan adanya validasi untuk dalam penelitian dan verifikasi secara cermat tentang kebenaran nilai transaksi yang digunakan sebagai dasar perhitungan BPHTB.

Validasi maksudnya adalah penelitian atas Surat Setoran Pajak Daerah (SSPD) BPHTB, yang dilakukan oleh petugas dinas yang berwenang, antara lain untuk meneliti kebenaran atas nilai yang digunakan untuk menghitung pembayaran BPHTB. Berdasarkan ketentuan Undang-Undang bahwa yang menjadi dasar perhitungan BPHTB adalah nilai transaksi.

Perbedaan nilai transaksi yang yang disepakati oleh para pihak dan dituangkan dalam akta dengan nilai transaksi yang digunakan sebagai dasar perhitungan BPHTB menurut penelitian dinas pendapatan, dalam hal ini terjadi ketidakpastian nilai mana yang benar, sedangkan kalau 
terjadi ketidaksesuain nilai transaksi yang sebenarnya, oleh karena jika terjadi sengketa dapat mengakibatkan aktanya jadi batal. Dari hasil validasi ada kemungkinan dari kurang bayar tersebut wajib pajak harus membayar lebih dari yang seharusnya. Dari data dan keterangan yang diperoleh bahwa antara nilai transaksi dengan NJOP PBB terdapat selisih yang beragam, tetapi cara umum nilai transaksi lebih tinggi dari NJOP PBB. (Hasil wawancara dengan A. Untung Lubis)

Berkaitan dengan nilai yang digunakan sebagai dasar perhitungan BPHTB, secara umum masyarakat mengetahui perhitungan BPHTB dihitung dari nilai NJOP PBB yang tercantum pada SPPT PBB . Disamping itu, masyarakat menghendaki adanya kepastian nilai yang digunakan sebagai dasar perhitungan BPHTB, sehingga mempermudah dan memberikan kepastian wajib pajak dalam menghitung berapa BPHTB yang harus di setorkan sejak awal. Sedangkan keterangan yang diperoleh dari hasil wawancara di Kantor BPPRD Kota Medan yang berwenang mengelola BPHTB menghendaki bahwa nilai yang digunakan sebagai dasar perhitungan BPHTB tetap menggunakan dasar nilai transaksi yang sebenarnya, dengan pertimbangan bahwa nilai tanah selalu mengalami perkembangan terutama kenaikan, sehingga tidak dapat ditentukan secara tetap (Hasil wawancara dengan A. Untung Lubis). Oleh karena itu juga tetap menghendaki adanya kewajiban validasi pembayaran BPHTB untuk meneliti kesesuaian objek pajak dan nilai transaksi yang sebenarnya.

Dengan demikian, menurut penulis pengenaan BPHTB dalam peralihan hak yang menggunakan harga transaksi sebagai dasar perhitungan BPHTB dirasa menjadi sulit dan tidak memiliki kepastian hukum. Dalam hal ini seharusnya ada sebuah kebijakan atau aturan khusus yang menentukan besarnya nilai NPOP yang menjadi dasar perhitungan BPHTB, sehingga memberikan kepastian hukum atas transaksi jual beli yang akan dibuat oleh para pihak yaitu menyangkut pembuatan akta jual belinya sekaligus memberi kepastian hukum terhadap akta jual beli yang dibuat oleh PPAT terkait, yang untuk selanjutnya digunakan sebagai dasar peralihan hak untuk melakukan proses balik nama pada Kantor Pertanahan Nasional.

\section{SIMPULAN}

Efektivitas validasi BPHTB terhadap ketidaksesuaian nilai objek pajak dilihat berdasarkan data penerimaan BPHTB tersebut diatas diketahui bahwa jumlah target dan realisasi pajak BPHTB terlihat untuk tahun anggaran 2017, penerimaan pajak BPHTB melebihi dari target yang telah ditetapkan, yaitu sebesar $119.46 \%$, hal ini berati tingkat efektivitasnya cukup efektif. Sedangkan untuk 2 (dua) tahun terakhir yaitu tahun 2018 dan 2019 penerimaan pajak BPHTB mengalami penurunan dari target yang telah ditetapkan masih mengalami selisih yang cukup besar, yaitu tahun anggaran 2018 sebesar $81.11 \%$ dan penurunan juga terjadi di tahun 2019, yaitu sebesar $81.80 \%$ dari target yang telah ditetapkan. Dengan begitu besarnya tingkat efektivitas pajak BPHTB pada tahun 2018 dan tahun 2019 berada pada kriteria Kurang efektif. Proses validasi BPHTB yang dilakukan oleh Badan Pengelola Pajak Dan Retribusi Daerah (BPPRD) Kota Medan secara umum sudah cukup memuaskan, ditambah lagi saat ini proses validasi SSPD BPHTB dilakukan dengan sistem online, sehingga proses validasi SSPD BPHTB menjadi lebih mudah dan cepat. Proses validasi BPHTB yang dilakukan oleh Badan Pengelola Pajak Dan Retribusi Daerah (BPPRD) Kota Medan sudah sesuai dengan standar SOP yang telah ditetapkan. Cara Menentukan Nilai Pokok Objek Pajak (NPOP) dengan menentukan nilai transaksi pada transaksi jual beli. Penggunaan nilai transaksi yang digunakan sebagai dasar perhitungan BPHTB ini seringkali menimbukan permasalahan. Perbedaan nilai transaksi yang yang disepakati oleh para pihak dan dituangkan dalam akta dengan nilai transaksi yang digunakan sebagai dasar perhitungan BPHTB menurut penelitian Badan Pengelolan Pajak dan Restribusi Daerah, dalam hal ini terjadi ketidakpastian nilai mana yang benar, sehingga menentukan NPOP yang sesuai dengan nilai objek pajak yang sebenarnya menjadi sulit, kecuali dengan dilakukan verifikasi lapangan atas objek BPHTB tersebut.

\section{DAFTAR PUSTAKA}

884 http://mahesainstitute.web.id/ojs2/index.php/jehss


Ambat, A., Sahari, A., \& Perdana, S. (2020). Penanggulangan Bentrok Massa Akibat Konflik Pertanahan Oleh Satuan Brimob Polda Sumatera Utara. Journal of Education, Humaniora and Social Sciences (JEHSS), 3(1), 70-77. doi:https://doi.org/10.34007/jehss.v3i1.195

Ariyanti, S., (2006), Pemungutan Bea Perolehan Hak Atas Tanah Dan Bangunan (BPHTB) Dalam Jual Beli Tanah Dan Atau Bangunan Di Kota Semarang. Masters thesis, Program Pasca Sarjana Universitas Diponegoro.

Ayza, B. (2018) Hukum Pajak Indonesia. Jakarta: Prenada Media Group.

Chairumi, (2014), Tinjauan Yuridis Terhadap Pemungutan Bea Perolehan Hak Atas Tanah Dan Bangunan (BPHTB) Dalam Transaksi Jual Beli Tanah Dan Bangunan Di Kota Tanjung Balai. Premise Law Journal, 4(1), 1-15.

Gukguk, A.R.. (2019). Jurnal Hukum. Sanksi Pajak Atas Bea Perolehan Hak Atas Tanah Dan Bangunan Kurang Bayar Yang Tidak Sesuai Dengan Nilai Perolehan Objek Pajak Yang Seharusnya Di Kota Medan. Program Studi Magister Kenotariatan Fakultas Hukum Universitas Sumatera Utara Medan.

Hernanda, B.A. (2014). Problematika Validasi Bea Perolehan Hak Atas Tanah Dan Bangunan Atas Temuan Hasil Verifikasi Lapangan Nilai Bangunan Tidak Sesuai Dengan Nilai Jual Objek Pajak Dan Nilai Perolehan Objek Pajak, Calyptra: Jurnal Ilmiah Mahasiswa Universitas Surabaya Vol.3 No.1.

Kadir, A. (2018). Analisis Penetapan Nilai Jual Obyek Pajak Bumi dan Bangunan Sektor Perkebunan sebagai Upaya Peningkatan Sumber Pendapatan Daerah. Journal of Education, Humaniora and Social Sciences (JEHSS). 1 (1): 9-15.

Mardiasmo. (2011). Perpajakan Edisi Revisi 2011. Yogyakarta: Andi Offset.

Marzuki, P.M. (2008). Pengantar Ilmu Hukum. Jakarta: Kencana Pranada Media Group.

Mulyoto, (2016). Legal Standing.Yogyakarta: Cakrawala Media.

Nainggolan, N. (2016). PENYELESAIAN SENGKETA TANAH HAK GUNA USAHA PT. EMHA DENGAN KELOMPOK TANI SEKAR RUKUN DI KECAMATAN SEI SUKA KABUPATEN BATUBARA. JURNAL MERCATORIA, 9(1), 19-34. doi:https://doi.org/10.31289/mercatoria.v9i1.321

Pratiwi, I. (2018). Analisis Efektivitas Pemungutan Dan Perhitungan Pajak Bea Perolehan Hak Atas Tanah Dan Bangunan Dalam Rangka Peningkatan Pendapatan Asli Daerah Kabupaten Batubara, Skripsi. Universitas Muhammadiyah Sumatera Utara. Medan.

Saleh, A., \& Kamello, T. (2014). KESADARAN HUKUM MASYARAKAT DALAM JUAL BELI TANAH DENGAN AKTA PPAT DI KOTA BINJAI. JURNAL MERCATORIA, 7(1), 1-13. doi:https://doi.org/10.31289/mercatoria.v7i1.656

Siahaan, M.P. (2003). Bea Perolehan Hak Atas tanah Dan Bangunan Teori Dan Praktek. Jakarta: Raja Grafindo Persada.

Siahaan, M.P. (2010) Kompilasi Peraturan Di Bidang BPHTB. Panduan Dalam Penyusunan Aturan Pelaksanaan Peraturan Daerah Tentang BPHTB. Yogyakarta: Graha Ilmu.

Siahaan, M.P., (2019). Pajak Daerah \& Retribusi Daerah. Jakarta. Rajawali Pers.

Soekanto, S. (1982). Kesadaran Hukum dan Kepatuhan Hukum. Jakarta: Rajawali Pers.

Soekanto, S. (2007). Faktor-Faktor yang Mempengaruhi Penegakan Hukum Jakarta: Raja Grafindo Persada.

Sunggono, B, (2001). Metodologi Penelitian Hukum, Jakarta: Raja Grafindo Persada.

Waluyo. (2010). Perpajakan Indonesia Edisi 10 Buku 2. Jakarta: Salemba Empat.

Wirawan, V. (2019). Kajian Tertib Administrasi Pertanahan Tanah Kasultanan dan Tanah Kadipaten Setelah Berlakunya Perdais Yogyakarta, Jurnal Ilmiah Penegakan Hukum, 6 (2) 2019: 161 - 171 